power at St. Louis; the nearby cities of Alton, Quincy, Warsaw, Hamilton, Nauvoo, and others on the Illinois side, Hannibal, Canton, Keokuk, Burlington, and Davenport on the Missouri-Iowa side, are striving to secure manufacturing, in which cheap power is needed, to consume the balance of the company's product.

The site of the power plant is 220 miles southwest of Chicago, 180 miles east of Kansas City and 137 miles north of St. Louis. Allowing for a transmission dis- tance as far away as Chicago, the plant is the center of population for about 4,000,570. Previous installations have shown that population has increased in the area affected to about five times the horse-power. If the rule follows in this case, the population within a radius of 50 miles of the power plant will jump to 1,500,000, which no doubt would consume all the energy that the company could produce. The great work portends a marvelous economic and social change for the region along this part of the famous Mississippi River. The great dam contains a little less masonry than went into building the pyramid of Cheops, and the work is all being done in two and $\mathbf{a}$ half years. It took 100,000 men a hundred years to build the pyramid. More daring than the Simplon tunnel, more useful than the $A$ pyian Way, it should be a monument to its builder when the Chinese Wall is a memory; the industrial pivot in a region swarming with humanity.

\title{
Iron, Vanadium and Carbon in Steel ${ }^{*}$
}

\section{Their Chemical and Mechanical Relations}

By Professors J. O. Arnold and A. A. Read

INTRODUCTORT.

THE influence of vanadium on iron and steel was di covered by one of the authors in the steel works of Sheffield University during a series of researches carried out from 1899 to 1902 . The experiments were made on ingots melted by the Huntsman crucible process, and in the acid open-hearth furnace. The results were not published in any journal, but were copyrighted at Stationers' Hall. The influence of vanadium, per se, was not very marked on structural steel, but in the presence of chromium, nickel, and tungsten, the results were almost magical. On tool steel, per se, and with other elements, the results were startling. It was pointed out that as the carbide residue on dissolving the steel in dilute sulphuric acid contained nearly all the vanadium, this element probably existed in the form of a carbide, or double carbide; but so far no systematic research has been carried out to determine the exact condition in which vanadium may be present in steel. The present communication is a continuation of the author's former work, and contains an account of a number of experiments made to determine:

1. The composition of the carbides separated from a series of well-annealed steels containing various percentages of vanadium, the percentage of carbon increasing with the percentage of vanadium.

2. The mechanical properties of the alloys under static and alternating stress tests.

3. The microscopical features of the alloys.

Moissan, by heating together vanadic anhydride and sugar carbon in different proportions and at various temperatures in the electric furnace, prepared several samples of vanadium containing from 4.4 to 18.42 per cent of carbon. Moissan also found that, if the heating be prolonged, a crystalline and well-defined carbide, having the formula $\mathrm{VC}$, is always obtained, which scratches quartz with ease, and is not attacked by hydrochloric or sulphuric acids.

Nicorlardot obtained the following double carbides of iron and vanadium; from steels with 0.4 per cent car bon, and 1.5 per cent vanadium, $\mathrm{Fe}_{3} \mathrm{C}, 38\left(\mathrm{~V}_{3} \mathrm{C}_{2}\right)$; from steels containing 0.8 per cent carbon and 10 per cent vanadium becomes richer in carbon as the vanadium with 9 per cent carbon and 32 per cent vanadium, $\mathrm{Fe}_{3} \mathrm{C}, 74 \quad\left(\mathrm{~V}_{4} \mathrm{C}_{3}\right)$. He also states that the carbide of vanadium becomes richer in carbon as the vanadium content of the alloy and the temperature of preparation is raised, and points out that this increasing amount of carbon found with the vanadium, as the temperature rises, confirms the results obtained by Moissan.

Guillet has examined microscopically two series of vanadium steels as forged, and has also determined their mechanical properties.

The constitution, the effect of annealing, and the mechanical properties of the two series of vanadium steels, are described by him as follows:

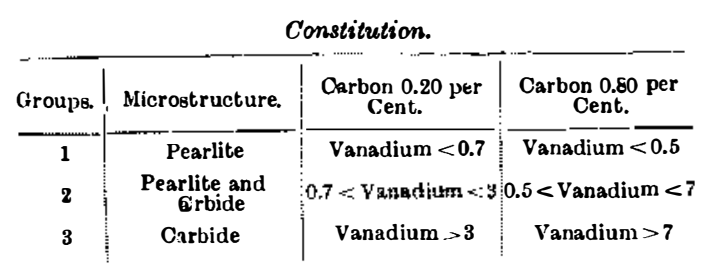

Annealing as a general rule softens vanadium steels In the pearlitic steels which contain much carbide, the carbon is precipitate as graphite, but steels with the carbide show only a slight modification.

Mechanical Properties-Pearlitic steels have a tensile strength and an elastic limit which rise rapidly with the percentage of vanadium; the elongation and reduction of area slowly decrease, while still preserving relatively high values; the brittleness does not increase the hardness increases rapidly.

Pearlitic and carbide steels have a tensile strength and an elastic limit which are lower in proportion as the percentage of ranadium, and consequently the

* Paper read before the Iron and Steel Institute, May 9th, 1912, and published in Engineering. amount of the carbide increases; the elongation and reduction of area increase, but the resistance to shock iminishes rapidly.

Steels containing the carbide have high elongations and reductions of areas, but they are very brittle. Paul Putz prepared a number of steels, with vanadium, increasing to 1.64 per cent, and carbon increasing to 2 per cent. The results of numerous tensile tests, and the examination of the sections of the steels of this series are described. The chemical formula for the vanadium carbide present in vanadium steels is stated to be $\mathrm{V}_{2} \mathrm{C}_{3}$, or $\mathrm{V}_{2 \mathrm{n}} \mathrm{C}_{3}$

Kent Smith describes his investigations on the properties of vanadium steels, and gives a summary of the effect of different quantities of vanadium on the static qualities of steel.

Giesen states that it is very difficult to judge correctly sections of vanadium steels under the microscope, since even a low vanadium content is completely dissolved by ferrite, the solution becoming saturated whên the vanadium reaches 0.6 per cent. Above this quantity the vanadium unites with the pearlitic carbon to form a vanadium carbide, which comes into prominence as the vanadium in the steel increases.

Portevin, working on steels containing 0.2 per cent carbon, and from 0.6 to 0.7 per cent vanadium, and also 0.8 per cent carbon, and from 0.25 to 10 per cent vanadium, arranges the vanadium steels in three groups: 1st Group. Pearlitic steels.

2d Group. Pearlitic and double carbide steels.

3rd Group. Double carbide steels.

Hatfield, from his experiments on the infiuence of vanadium upon the physical properties of cast irons, comes to the following conclusions, among othersthat silicon is partially prevented from crystalizing with the carbide by vanadium, and that by the presence of much of the vanadium in the carbide, the carbide is rendered more stable.

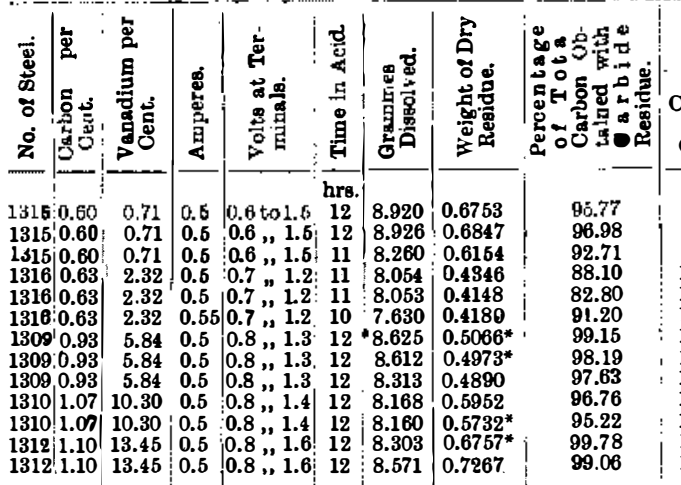

\section{* These carbide residues were boiled for 1 hour with dilute sulphuric acid
and dried in the usual was}

METHOD OF MANUFACTURE OF' THE AUTHORS' STEELS.

The alloys were made by the cole crucible process in Sheffield white clay pots from Swedish bar iron American washed iron, and $3 S$ per cent ferro-vanadium; 0.05 per cent of metallic aluminium was added to each a few minutes before teeming. The ingots, $23 / 4$ inches square, and each weighing 40 pounds, were cogged and hammered into bars $1 \frac{11}{8}$ inch round. The bars were heated to about 950 deg. Cent. for six hours, and were allowed to cool during an additional twelve hours.

CHEMICAL, COMPOSITIONS OF AUTHORS' SERIES,

The analyses of the steels were 'made on the last turnings from the carbide bars. 'The results are given in Table I

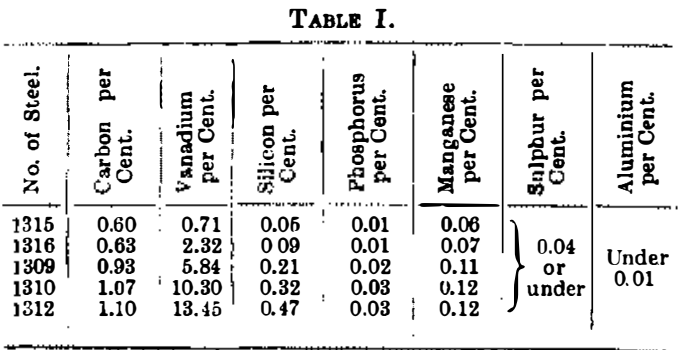

DETERMINATION OF THE CARBIDES.

The method and treatment used for separating the carbides was that described in the authors' former paper, ${ }^{1}$ but with this modification, that the residues were dried at 100 deg. Cent. in a current of hydrogen, the tube being pumped out from time to time. The steels dissolved quite readily, and with each member of the series vanadium was found in the hydrochloric acid solutions; but in most cases it was quite unnecessary to test for vanadium, as the electrolyte was distinctly blue to dark-blue in color.

The carbides obtained from Nos. 1315 and 1316, containing 0.71 and 2.32 per cent of vanadium, were darkgray ; and from Nos. 1309, 1310, and 1312, containing $5.84,10.30$, and 13.45 per cent of vanadium, slate-gray in color.

The analysis of the carbides were carried out as follows: The porcelain boat containing the dried carbide was weighed. About one half of the carbide was carefully removed and put on one side for the deter mination of iron and vanadium. The boat was again weighed, the carbide well mixed with pure manganese dioxide, and the carbon estimated by direct combustion. The remaining portion of the carbide was intimately mixed with sodium carbonate and a small quantity of sodium peroxide in a platinum basin, and heated in a muffle furnace. When cold, the mass was repeatedly boiled with water and filtered. The vanadium in the filtrate was estimated by reducing with sulphurous acid and titrating with a standard solution of potassium permanganate. The residue on the filter paper was dissolved in hydrochloric acid and made up to a known volume. The iron was then estimated by the usual volumetric process, using a standard solution of potassium dichromate for the titration. The very small quantity of vanadium found in the iron solution was determined by the hydrogen peroxide color test. The results are given in Table II.

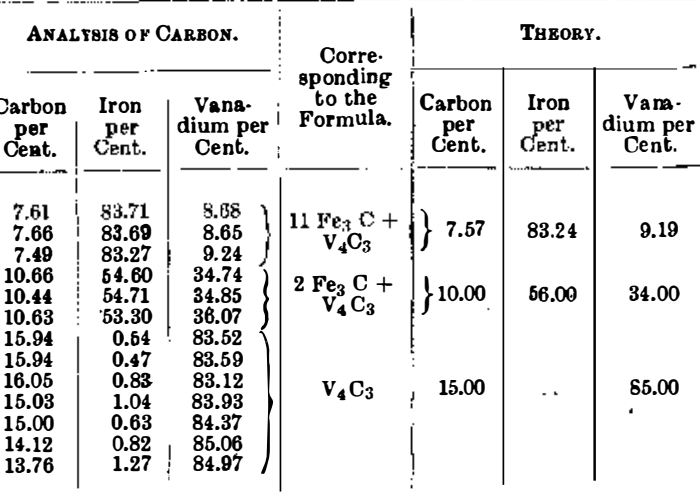

A consideration of the results in the foregoing table indicates that in most cases practically the total amount or carbon in the steel is obtained as carbide. The

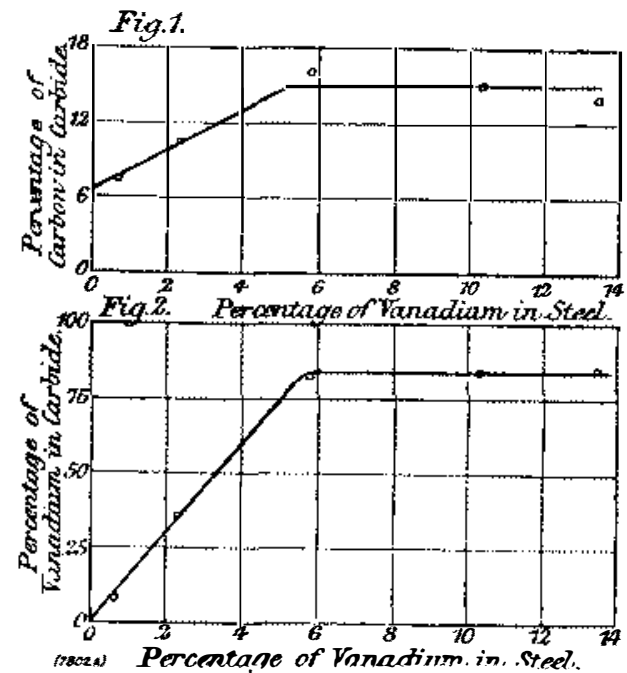

Joural of the Iron and Steel Institute, 1911, No. 1, page 


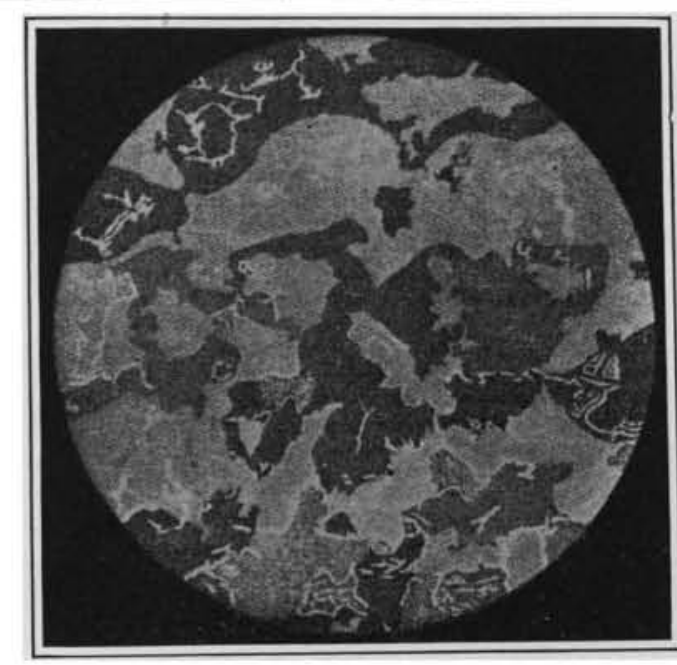

Fig. 3.-Micrograph No. 1. Carbon, 0.60 per cent; vanadium, 0.71 per cent
Magnified 180 diameters.

slightly lower results are not due to any appreciable decomposition of the carbide during the electrolytic run, but are accounted for by a slight roughness of the bars which prevented the last traces of carbide being obtained.

The results given in Table II also show that vanadium replaces iron in the carbide, even when the steel contains only such a small quantity as 0.71 per cent of vanadium, with the formation of a mechanical mixture of the carbides of iron and vanadium corresponding to the formula $11 \mathrm{Fe}_{3} \mathrm{C}+\mathrm{V}_{4} \mathrm{C}_{3}$.

As the vanadium in the steel increases, more vanadium is found in the carbide, and with the next member of the series, containing 2.32 per cent of vanadium, the carbide is represented by the formula $2 \mathrm{Fe}_{\mathrm{O}} \mathrm{C}+\mathrm{V} \mathrm{C}_{3}$

Coming to the remaining three steels of the series, with 5.84, 10.30, and 13.45 per cent of vanadium, in each with $5.84,10.30$, and 13.45 per cent of vanadium, in each
case practically the whole of the iron has been replaced by vanadium, and most probably a definite carbide of vanadium is obtained corresponding to the formula $\mathrm{V}, \mathrm{C}_{3}{ }^{2}$

These results are shown more clearly in Figs. 1 and 2 It will also be noticed (Table II) that it is possible to reduce still further this small quautity of iron found with the vanadium by digesting the carbide residues with hot dilute sulphuric acid.

TURNING CHARACTERISTICS OF THE ALLOYS.

The report of Mr. J. Harrison, laboratory engineer in the Metallurgical Department of Sheffield University, on the behavior of the bars in the lathe is embodied in the following table, the word "tough" having reference to the capability of the material to curl off in spirals during the turning operations:

\begin{tabular}{|c|c|c|c|}
\hline $\begin{array}{l}\text { Steel No. } \\
\text { A. }\end{array}$ & $\begin{array}{c}\text { Carbon } \\
\text { per Cent. }\end{array}$ & $\begin{array}{l}\text { Vanadiun } \\
\text { per Cent. }\end{array}$ & Turning Report. \\
\hline $\begin{array}{l}1315 \\
1316 \\
1309 \\
1310 \\
1312\end{array}$ & $\begin{array}{l}0.60 \\
0.63 \\
0.93 \\
1.07 \\
1.10\end{array}$ & $\begin{array}{r}0.71 \\
2.32 \\
5.84 \\
1030 \\
13.45\end{array}$ & $\begin{array}{l}\text { Tough. } \\
" \# \text { and olightly hard. } \\
\# " \text { nard. }\end{array}$ \\
\hline
\end{tabular}

The static results are embodied in the followin table, the test-pieces being 2 inches parallel and 0.56 inch in diameter

\begin{tabular}{|c|c|c|c|c|}
\hline $\begin{array}{c}\text { Sreel No. } \\
\text { A. }\end{array}$ & Yield-Point. & $\begin{array}{l}\text { Maximuin } \\
\text { Stress. }\end{array}$ & Elongation & $\begin{array}{c}\text { Reduction } \\
\text { of Area }\end{array}$ \\
\hline $\begin{array}{l}1315 \\
1316 \\
1309 \\
1310 \\
1312\end{array}$ & $\begin{array}{c}\text { tons par sq. in. } \\
12 \\
14 \\
17 \\
15 \\
18\end{array}$ & \begin{tabular}{|c} 
tons per sq. in. \\
35.9 \\
35.0 \\
33.4 \\
33.7 \\
37.0
\end{tabular} & \begin{tabular}{|c|} 
per cent. \\
22.0 \\
24.5 \\
25.0 \\
23.0 \\
10.0
\end{tabular} & \begin{tabular}{|c} 
per cent. \\
41.4 \\
52.0 \\
53.2 \\
31.5 \\
9.7
\end{tabular} \\
\hline
\end{tabular}

${ }^{2}$ It is theoretically possible that this may be a mixture of vanadium carbides.

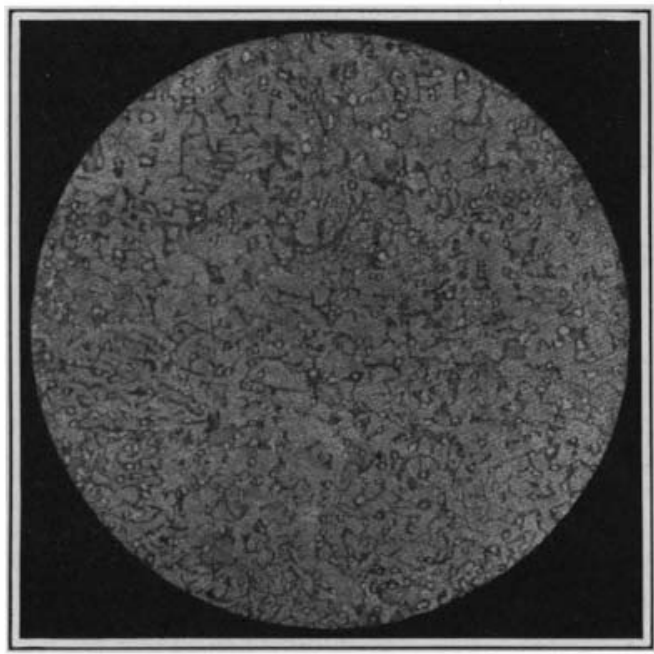

Fig. 6.-Micrograph No. 4. Carbon, 1.10 per cent.; vanadium, 13.45 per cent

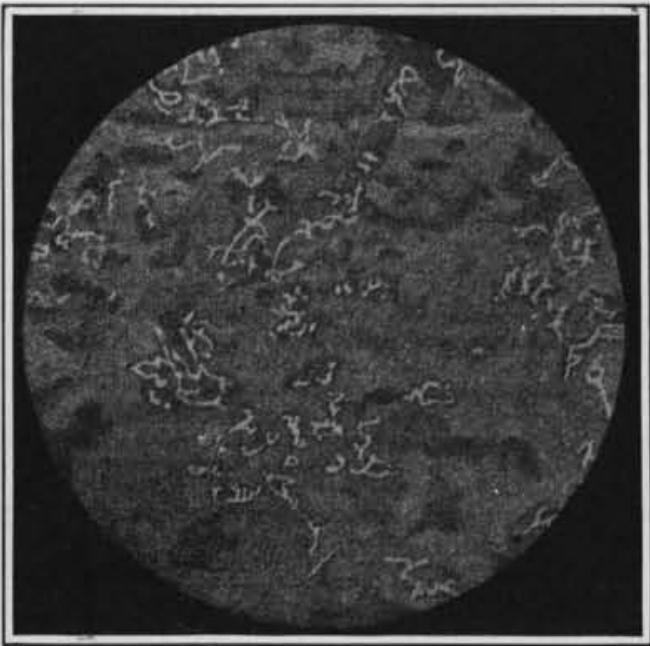

Fig. 4.-Micrograph No. 2.

Carbon, 0.63 per cent; vanadium, 2.32 per cent. Magnified 180 diameters.

ALTERNATING STRESS TESTS.

The dynamic tests obtained under standard cond tions of the Arnold machine are tabulated as follows:

Table of Alternating q'ests.

\begin{tabular}{c|c|c|c}
\hline \multirow{2}{*}{$\begin{array}{c}\text { Steel No } \\
\text { A. }\end{array}$} & \multicolumn{3}{|c}{ Altrrnations Endured } \\
\cline { 2 - 4 } & First Teat. & Second Test. & Mean. \\
\hline 1315 & 128 & 112 & 119 \\
1315 & 182 & 220 & 101. \\
1309 & 114 & 128 & 185 \\
1310 & 94 & 144 & 119 \\
1312 & 8 & 22 & 16 \\
\hline
\end{tabular}

The poor dynamic properties of the series exemplify the evil influence of drastic annealing on vanadium steels.

MICROGRAPHIC ANALYSIS.

The microscopical examination of the steels leads the authors to announce provisionally the discovery of two new constituents: 1 . Vanadium pearlite; 2 . Vanadium cementite, $\mathrm{V}_{4} \mathrm{C}_{3}$.

\section{Vanadium Pearlite}

This constituent seems incapable of segregating into the laminated variety, and presents itself only in the troostitic and sorbitic forms. Its saturation point seems considerably higher than that of iron pearlite, but this point requires further research.

\section{Vanadium Cementite.}

This constituent (a decomposition product of vanadium pearlite) is not nearly so mobile as $\mathrm{Fe}_{3} \mathrm{C}$, and consequently segregates into relatively minute irregular masses very much smaller than massive iron cementite. The micrographic analy'sis has proved, almost beyond doubt, that there is no double carbide of iron and vanadium, since when $\mathrm{Fe}_{3} \mathrm{C}$ and $\mathrm{V}_{4} \mathrm{C}_{3}$ are together in a well-annealed steel, the former has segregated as usual, while the latter has remained distributed in its pearlite in the troostitic or sorbitic form.

Micrograph No. 1.-In this structure was found (a) a pale ground mass of slightly vanadiferous ferrite; (b) a few areas of laminated iron pearlite; $(c)$ the $\mathrm{Fe}_{3} \mathrm{C}$ of decomposed laminated iron pearlite in the form of cell walls and irregular masses; $(d)$ dark etching troostitic $^{3}$ vanadium pearlite; $(e)$ less-dark etching areas of sorbitic ${ }^{4}$ vanadium pearlite. This section contains 0.6 per cent of carbon and 0.71 per cent of vanadium (Fig. 3).

${ }^{3}$ The term "troostitic" has reference to pearlite, in whic the carbide is in a state of division so fine as to be beyond the carbide is in a state of dion
the range of microscopic vision.

"The term "sorbitic," as used in this paper, has reference

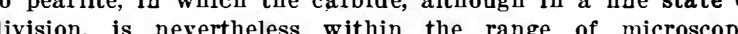
vision.

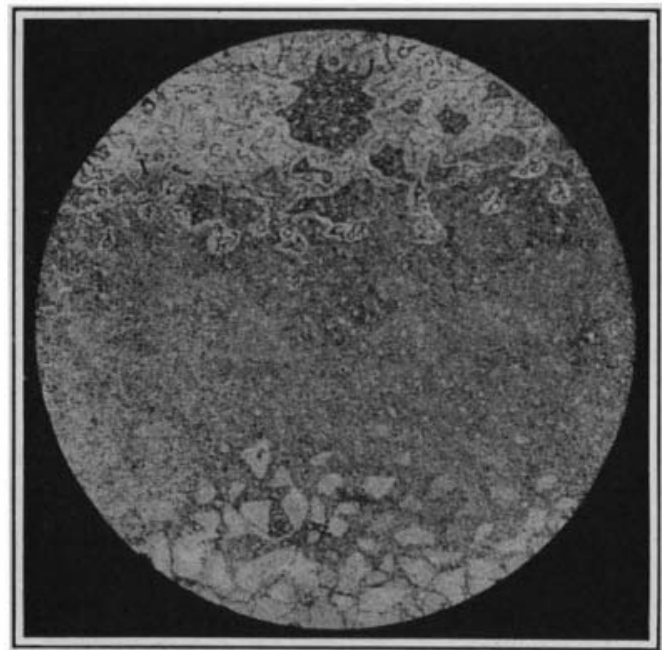

Fig. 7.-Micrograph No. 5 Carbon, 1.10 per cent; vanadium, 13.45 per cent. Quenched

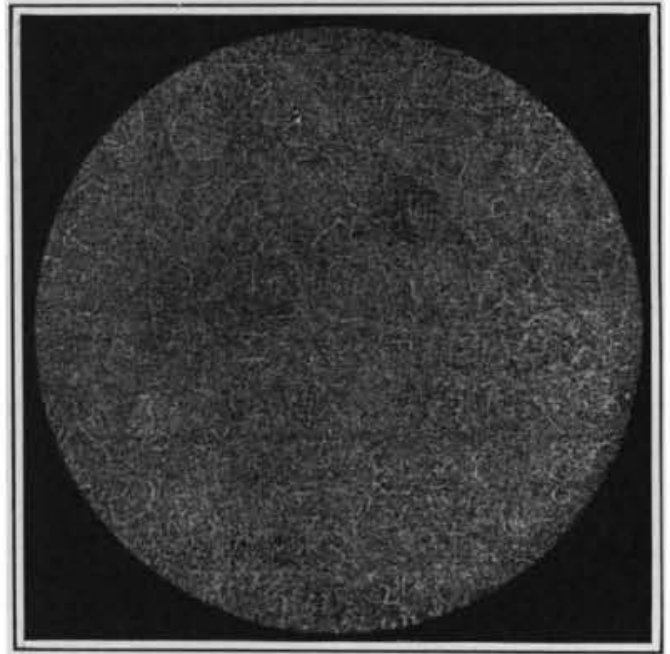

Fig. 5.-Micrograph No. 3

Carbon, 0.93 per Magnified 180 diameters.

Micrograph No. 2.--This steel presents a very confused structure, in which vanadiferous ferrite and vanadium pearlite in both the troostitic and sorbitic forms have segregated very imperfectly in spite of the twelve hours' cooling. The only well-defined constituent is the iron cementite which has readily segregated in meshes and masses, but is distinctly less in quantity than that in Micrograph No. 1 . The steel represented in Micrograph No. 2 contains 0.63 per cent carbon and 2.32 per cent vanadium (Fig. 4).

Micrograph No. 3.-This section consists largely of sorbitic vanadium pearlite, overlaid, however, by irregular meshes, apparently of vanadiferous ferrite In other words, the steel is not saturated. It contains 0.93 per cent carbon and 5.84 per cent vanadium (Fig. 5).

Micrograph No. 4.-This contains 1.10 per cent car bon and 13.45 per cent vanadium. It is almost identical in structure with steel No. 1310, which contains 1.07 per cent carbon and 10.30 per cent vanadium. The ground mass is vanadiferous ferrite, over which are scattered small segregated irregular masses of vanadium cementite, $\mathrm{V}_{4} \mathrm{C}_{3}$. Each particle is environed by a somewhat dark border of probably sorbitic vanadium pearlite, and small patches and streaks of this constituent are also scattered over the field. The mobility or segregative capacity of $\mathrm{V}_{4} \mathrm{C}_{3}$ obviously increases with the percentage of vanadium present in the ferrite (Fig. 6).

A New Industry for Malaysia.-It has been proposed to start in Malaysia a small export trade in shark's liver oil. This oil is refined in Europe and sold as cod liver oil. There are several species of these sharks, and they ordinarily run from 7 to 15 feet in length, the girth being of nearly the same dimensions. They a re speared in large numbers by people skilled in catching them. They are found in pairs, and the har pooners try to kill the male first, in which case they are able also to spear the female as it does not desert its mate. The liver of an 11-foot shark gives about 5 gallons of oil. The oil brings $\$ 73$ a ton.-Consular Report.

_Volatitity of Platinum. - Sir William Crookes has brought before the Royal Society the results of some experiments which indicate that platinum is volatile below its melting point. At 1,300 deg. Cent. a platinum crucible lost 0.245 per cent of its weight. Palladium lost 0.745 per cent and iridium 7 per cent after 2 hour exposure. At 900 deg. Cent. platinum lost no weight, but palladium lost 0.09 per cent in 10 hours and iridium 0.09 per cent in 20 hours. In a vacuum at 1,300 degrees iridium volatilized to an appreciable extent, with condensation in the cooler portion of the quartz tube.

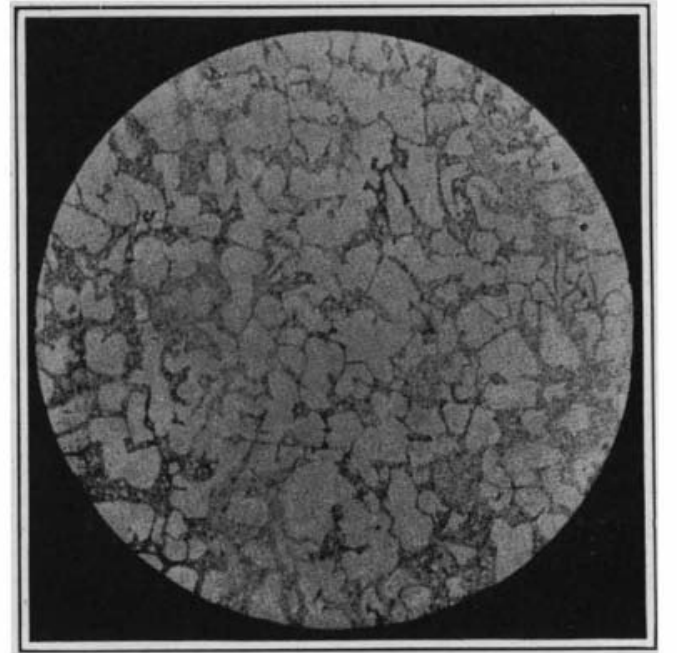

Fig. 8.-Micrograph No. 6 . Carbon, 1.10 per cent; vanadium, 13.45 per cent. Full field
of lower area shown in Micrograph No. 5. 180 diameters. 